SBSの成因に関しては，従来から下行説（膿汁吸引 説, リンパ・血行説, 病巣感染説, 連続感染説, 鼻呼 吸障害説)，上行説，同時発生説（体質素因の関与）な どの諸説があるが不明な点が多い。これらの諸説のな かでも，滕汁吸引説をはじめとして副䙹腔炎から下行 性に気管支炎が進展する，いわゆる下行説が重視され てきた.確かにSBS の多くの症例では幼小児期より鼻 症状が先行出現し，咳・痰などの下気道症状は青年期 以後に出現する。しかしながら，副鼻腔根本手術後に 下気道症状が発現するものも多く，術後皋症状が軽快 しているにもかかわらず，新たに下気道症状が発現す るものがある.これらの例ではすでに潜在していた下 気道病変が顐在化したか，あるいは上・下気道全体の 易䍜患性をもつ個体が，鼻副鼻腔要因とは別に下気道 疾患の発症をみたとも考えられる。また，慢性副鼻腔 炎で下気道症状を招来するものは必ずしも多くない。 さらに気管・気管支粘膜の粘液線毛系は末梢からの候 頭側へ排出機能を有しており，後鼻漏が気管内に停滞 することはすでに病変が下気道に存在していることも 考えられる。

一方, SBS は家族内発生頻度が高く. 二親等以内の 血緑者にSBSないしは慢性副鼻腔炎の家族歴を有し

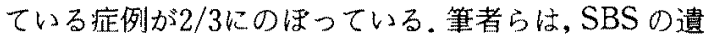
伝性素因をより明らかにするためにSBS46 例におい て HLA 抗原の検討を行った。その結果, BW54 が
NBSでは $50.0 \%$ に出現し, 高度の相関を認めた $\left(\mathrm{X}^{2}\right.$ 值 33.0, Pc 值 $\left.8.31 \times 10^{-8}, \mathrm{R}, \mathrm{R}, 7.76\right)$ 。一方, 慢性副 鼻腔炎単独群, 慢性気管支炎単独群では, BW54 の出 現頻度は対照群と有意差を認めなかった。 SBSを下気 道の病型別にびまん性沉細気管支 (diffuse panbronchiolitis, 下DPB と略す)群19例，および慢性気管支 炎・気管支拡張症群27例に分けて BW54 の出現頻度を みると, DPB では68.4\%と SBS 全体よりもさらに高 度な出現率と相関がみられた $\left(\mathrm{X}^{2}\right.$ 值 $36.2, \mathrm{Pc}$ 值 $2.04 \times 10^{-9}$, R. R. 16.8).このことから, SBS なかでも DPB は Bw54をマーカーとする遺伝的体質を基礎と するものであり, 慢性副鼻腔炎単独群, 慢性気管支炎 単独群のいずれからも区別されるべき独立した疾患で あることが示唆された。

現時点では，Bw54をマーカーとする遺伝性体質素 因がどのような機序を介して本症候群の発症をもたら すのかは不明である。それは気道感染防御系の障害， すなわ方気道の易感染性とその遷延化に関係するもの であるのか，あるいは感染によっておこされる免疫学 的な生体反応の特異性であるのか, それともさらに別 の機序によるものなのか, これらは今後の検討課題で ある。また, Bw54 はモンゴリアン特異抗原とされてお り，そのことが今日，DPB が欧米ではほとんどみられ ず，わが国にかなり特有のものであると考えられつつ あることと関連するか否かも興味深い点である.

\title{
（5）小児科の立場から
}

\section{吉田豊 (日医大・小児科)}

小児科領域においても, 気管支喘息をはじめ, 反復 性, 遷延性傾向のある呼吸器疾患が増加している。こ れら疾患と副鼻腔との関連を検索するためにX線的に 副鼻靕撮影を行いその結果と小児のImmotile cilia symdromeについても報告した。

副鼻空 X線検査の対象は211例, 喘息175, 反復性気 管支炎 18 , 気管支拡張症 4 など, 年齢は 1 〜 歳 97 , $7 \sim 12$ 歳 $93,12 \sim 15$ 歳21などでX 線検査沈 Water 撮 影, Caldwel 撮影によった。

Water 撮影による上䪽洞検查で，上靧洞に明らかな 異常陰影がみとめら机たものは，4歳未满は上顎洞部 位への軟部陰影の重複などの影響を考慮して，5歳以 上についてみると， $5 \sim 6$ 歳 $29.6 \%, 7 \sim 8$ 歳 $22.9 \%$, $9 \sim 10$ 歳 $16.6 \%, 11 \sim 12$ 歳 $17.9 \%, 13 \sim 14$ 歳 $23.4 \%$, 15 歳以上 $50 \%$ で, 小児の反復遷延性呼吸器疾患の 17〜 50\%に上滪洞に異常陰影がみとめられた。この陰 影をもって直ちに上䫑洞炎と診断することは慎重でな ければならないが，年齢の低い者は副鼻腔炎の特有な 症状は認めがたいともい机，X線検査によってのみ 診断しうるものが多いことから考えれば，気管支喘息 をふくめて小児反復性・遷延性呼吸器疾患では副鼻腔 炎の合併がかなりの程度にみとめられた。

Caldwel 撮影による前頭洞発育についての検索を上
顎洞検査症例と同一症例についてみると, true frontal

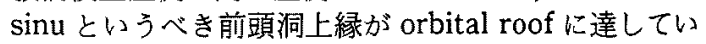
るか，これを越えているものを明らかな前頭洞発育あ りとする $5 \sim 6$ 歳 $26.3 \%, 7 \sim 8$ 歳 $38.6 \%, 9$ 歳を過 ぎると $70 \%$ にも及び，健常小児と同様な傾向を示した が, 13 歳を過ぎても前頭洞陰影の未出現症例は 4 例で, これは気管支拡張症 2, Kartagener 症候群 1 , 気管支 喘息1であった。これは乳幼児期の反復・要延的な炎 症に関係するとか，あるいは体質要因の関与を示唆す るものであるとかいわ机ているが，少なくとも前後洞 発育と反復遷延下気道疾患のあるものとがなんらかの 関係を有していることが示唆された。

1969年以降, 気管支拡張症は気道感染症に対する抗 生剂療法によって激減し，1973年以降は，その発症は なんらかの素因があるものに限られてきた。近年 Immotile cilia syndrome (Dyskinetic cilia syndrome) の疾患概念がみとめられ, 小児の気管支拡張症, 遷延 性下気道感染症に対して気道線毛超微細構造の検索が 行われるようになった。

Immotile cilia syndromeについては私がいた Trousseau 小児病院 (パリ) の小児呼吸器科での46例とわれ われの教室の 4 例の計50例についてみると, 気管支拡 張症は25例でこのうち12例は Kartagener 症候群であ 
った。線毛超微細構造の異常は, dynein arme の両側 あるいは一側の欠損が43, central complexの異常が 7であった. 430 dynein armeの欠損のう方 central complex 異常合弁 1, peripheral linkage 欠損合弁 4 などもみられた。

Immotile cilia syndrome 怔気管支拡張を必ずしも
有しているものでなく，小児においても非常にまれな 呼吸器疾患であるとおもわれない. Kartagener 症候 群の発生頻度から類推すれば 1：15〜30.000というも のもある。

小児反復・遷延性呼吸器疾患にたいしては鼻腔から 肺胞までの一連の気道病変の検索が必要である。

\title{
4. 遅発性内リンパ水腫
}

\author{
司会 原 田康夫(広島大)
}

一側隼の既往をもつものにめまいが好発すること は，1971年に亀井らにより報告された。1975年に Nadol らおよびWolfson and Leiberman が, 先行す る高度内耳性難聴を有する患者で，年余を経てメニエ ール病に類似しためまいを起こすものがあることを報 告した。また Nadol らは，手術時の所見やその際採取 した内耳液などより，これらの病態に内リンパ水腫が 関与していることを推察している。その後, Suhuknecht が遅発性内リンパ水腫という概念をこれらの症例 に適用し，今日に至っている。

遅発性内リンパ水腫をきたす原因疾患としては，外 傷, 流行性耳下腺炎, 細菌性内耳炎など種々のものが 報告されているが，本疾患（あるいは症候群）は，そ の存在を知らないと診断に苦慮し，思わぬ混乱を招く ことが十分に考えら机る。

今回のパネルでは，まずその疾患概念について原田 が述べ, 平川勝洋氏に遅発性内リンパ水腫の成立機転, 内リンパ水腫の病態, 水腫よりめまい発症の機序につ いて解説してもらった，松崎充男氏には原因疾患別の 連発性内リンパ水腫の頻度や，一側性熊患者でめまい
を起こす症例の統計など疫学的なことについて発表し ていただいた，高橋正紘氏には主に病歴，病状，検査 所見などからの診断法について，さらに，鑑別疾患に ついても発表していただき，最後にメニエール病より も薬物治療に抵抗するとされる本疾患（症候群）の治 療に関しては二木隆氏に扝願いした。

以上のアウトラインを基に特に以下のことについて 討論した。

1）本疾患（症候群）の定義, 特に聴力障害の程度, 恥力障害からめまい発症までの期間

2）治療法，特に対側型について

3）両側型の患側の決定と治療法について

本疾患 (症候群) の剖検例の報告は少なくメニエー 儿病と同様にその病態については，不明な点が多い。 しかし, 本疾患（症候群）の上うな症状を呈する例が 存在することは事実である. 症例の蓄積が病態の解明, 治療法の開発，改善の最重要加最短の道々考光る。 会員諸氏に本疾患の概要をご理解頂ければ幸いであ る.

\section{（1）遅発性内リンパ水腫の診断}

高 橋 正 紘（慶大）

遅発性内リンパ水腫を診断する上で参考となる，従 来の報告例の統計的資料，自験例および問題点につい て述へた。

\section{1. 診断基準}

Shuknecht の定義によれば，遅発性内リンパ水腫と は原因不明あるいは既知の炎症・外傷の一側高度難聴 の発症後，年余を経て回転性めまいの反復あるいは良 聴耳の聴力変動を来す症候群である。この定義を診断 基準として用いる場合，高度難聴の程度，発症までの 期間，めまいの反復や聴力変動の程度をどこまで含め るかの問題が生じる。ささらに内リンパ水腫を客観的に 裹付ける検査をどの程度診断の条件とするかが問題と なる。

\section{2. 原因疾患}

国内外の報告例156例でみると，難聴の原因疾患は原

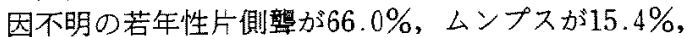
架発性難聴が $7.1 \%$, 麻疮, 頭部外傷が $3.1 \%$ の順とな つている. 原因不明とウイルス疾患を合わせると全体

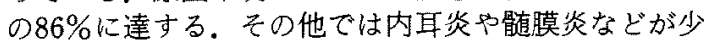
数例報告されている。

\section{3. めまい発症までの期間}

高度難聴発症後めまい出現までの期間は 5 年末満 が16.5\%，5-10年が14.8\%，10-15年が18.3\%で， 最初の 15 年で全体の $49.5 \%$ を占める。一方, 20 年以上 経過して発症した例も $42 \%$ 報告されており，本当に難 聴とめまいの間に因果関係があるかいなか疑問を抱か 